\title{
https://doi.org/10.46813/2021-134-085 \\ CONSTRUCTIONAL MATERIALS EXPERIMENTAL RESEARCHES ON THE HELIUM IONS LINEAR ACCELERATOR
}

\author{
V.I. Butenko, S.N. Dubniuk, A.F. Dyachenko, A.P. Kobets, O.V. Manuilenko, K.V. Pavlii, \\ V.A. Soshenko, S.S. Tishkin, B.V. Zajtsev \\ National Science Center "Kharkov Institute of Physics and Technology”, Kharkiv, Ukraine \\ E-mail: dubnjuk@kipt.kharkov.ua
}

The basic parameters of an irradiation and their registration system for constructional materials irradiated on the helium ions linear accelerator are resulted. Experimental techniques and some researches results of the microscopic, electrophysical, frictional and ultrasonic characteristics of atomic power stations (APS) and fusion reactors (FR) constructional materials irradiated on a linear accelerator of the helium ions with energies 0.12 and $4 \mathrm{MeV}$ are presented.

PACS: 29.17.w, 29.27.Bd

\section{INTRODUCTION}

An atomic power engineering development puts in the forefront safety and reliability problems of nuclear power facilities (NPF), their economy and ecological cleanliness $[1,2]$. One of the basic conditions of these problems decision is application of materials (fuel, constructional, absorbing, etc.), satisfying necessary requirements. The basic goal of researches is receiving of experimental data for perfection used and creation of new materials for NPF various type.

Development of a thermonuclear power, taking into account necessary requirements on safety and reliability, is defined by an optimum set of constructional materials for each of reactor knots and systems from the point of view of such materials availability and their cost $[2-6]$. The most rigid requirements are produced to materials of the first wall and FR diverter. For them the acceptable set mechanical, thermalphysic, corrosive, activational, etc. properties which will define operational characteristics of the reactor should be found.

Therefore, only the complex approach to studying of radiating characteristics will allow to define the basic types of perspective materials for nuclear and thermonuclear power.

\section{PARAMETERS OF THE CONSTRUCTIONAL MATERIALS IRRADIATION ON THE HELIUM IONS ACCELERATOR}

Now the majority of researches directed on studying of radiating damages, are carried out by means of ionic implantation. For studying of the processes connected with an irradiation of constructional materials in NSC KhIPT the linear accelerator $\left(\mathrm{He}^{+}\right)$of the helium ions with energies 0.12 and $4 \mathrm{MeV}[7,8]$ is applied. In accelerating structure of an interdigital H-type for beam focusing the method of alternating-phase focusing with step-by-step change of a synchronous phase along the focusing periods $[9,10]$ is used. For beam injection in accelerating section the injector of helium ions which consists of a duoplasmatron type source with oscillate electrons in anode area, extraction and beam focusing systems, and also an accelerating tube [8] is applied.
On the linear accelerator of the helium ions the chamber for an irradiation with energies 0.12 and $4 \mathrm{MeV}$ of the constructional materials and research of their characteristics and as the system of experimental parameters measurement is created [11].

In the chamber vacuum is carried out with the help vacuum and turbo-molecular pumps, it provides oxygen-free environment in the chamber volume and the same vacuum as in accelerating structure.

A temperature of the sample is set by the heating element located directly in the irradiation chamber and measured by the thermocouple attached to the sample.

For increase of a current density of a beam which falling on the sample and reduction of an irradiation time in front of a chamber the focusing triplet is established. Triplet allows to change beam radius, and, hence, and a current density depending on experiment requirements. It has allowed to increase current density of a beam falling on a target in 3-7 times and has made value of $1.2 \cdot 10^{13}$ part./s in a spot diameter of $\sim 1 \mathrm{~cm} \mathrm{[12].}$

Beam currents are measured by means of the induction contactless flying gauges established on an input and an output from a triplet, and as directly ahead of the irradiated sample [13]. With application of Kalman filter "thermal" noise of induction gauges managed to be lowered to $2 \%$.

Basic parameters of the helium ions beam at samples irradiation are resulted in the Table 1.

Table 1

Parameters of samples irradiation

\begin{tabular}{|l|c|}
\hline \multicolumn{1}{|c|}{ Parameter } & Value \\
\hline Pulse current & $700 \ldots 900 \mathrm{mkA}$ \\
\hline Pulse length & $500 \mathrm{mkc}$ \\
\hline Repetition frequency & $2 \ldots 5 \mathrm{imp} . \mathrm{c}$ \\
\hline Average current & $0.7 \ldots 2 \mathrm{mkA}$ \\
\hline Current density & $(0.15 \ldots 0.44) \cdot 10^{13} \mathrm{part} . \mathrm{cm}^{2}$ \\
\hline Temperature & to $900^{\circ} \mathrm{C}$ \\
\hline
\end{tabular}

For registration of irradiated samples parameters were used digital oscillograph ZET-302 and DAC/ADC ZET210 which were connected to the computer with the further processing of the measured data were used. In system SCAD ZETView programs for interaction with DAC/ADC ZET-210 and ZET-302 have been developed [11]. 
During an irradiation of samples following parameters, such as a sample temperature, a beam current and the form beam falling on the sample, an irradiation dose, profiles of ionization, damageability and helium occurrence in the sample are measured [11]. In the Table 2 ranges and measurement errors of the basic experimental parameters are resulted.

Ranges and measurement errors of the experimental parameters

\begin{tabular}{|l|c|c|}
\hline \multicolumn{1}{|c|}{ Parameter } & Range & Error, $\%$ \\
\hline Pulse current & $400 \ldots 1200 \mathrm{mkA}$ & \pm 2 \\
\hline Pulse length & $450 \ldots 800 \mathrm{mkc}$ & \pm 1.65 \\
\hline Temperature & $20 \ldots 1000^{\circ} \mathrm{C}$ & \pm 1 \\
\hline
\end{tabular}

\section{RESEARCH TECHNIQUES CALCULATED CHARACTERISTICS}

The understanding of radiating influence mechanisms is a basis of steady constructions designing NPF and FR and working out of new materials steadier against radiating influences.

For calculation of ions range in firm bodies various programs of computer modeling are used. Software package SRIM uses wide popularity [14, 15] which along with possibility of ranges calculation allows to receive following important information: distribution of vacancies in targets, atoms redistribution of irradiated materials, dispersion factors, the phenomena connected with loss of ions energy, the distribution of ionization and formation phonons etc.

Before samples irradiation in the program SRIM all listed processes were calculated, taking into account cascades of displacement for irradiated materials. For an example on the Figs. 1, 2 profiles of atoms redistribution and damageability in the alloy EI-993 irradiated with the helium ions with an energy of $0.12 \mathrm{MeV}$ are resulted.

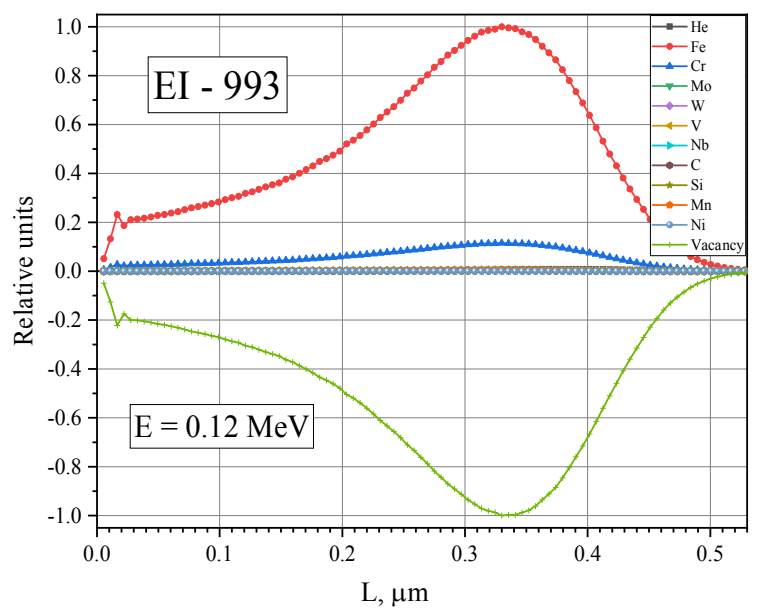

Fig. 1. Occurrence (the top curves) and damageability (the bottom curve) profiles in the alloy EI-993 at an irradiation energy of $E_{\mathrm{He}}=0.12 \mathrm{MeV}$

From these figures follows that there is a change of a material density along of helium ions range. In the Table 3 energy losses on ionization, damageability and formation phonons are presented. Whence follows that the basic part of helium ions energy in a range
$0.12 \ldots 4 \mathrm{MeV}$ goes on ionization of the sample and only less than $0.33 \%$ go on damageability. Such calculations are made for all irradiated samples.

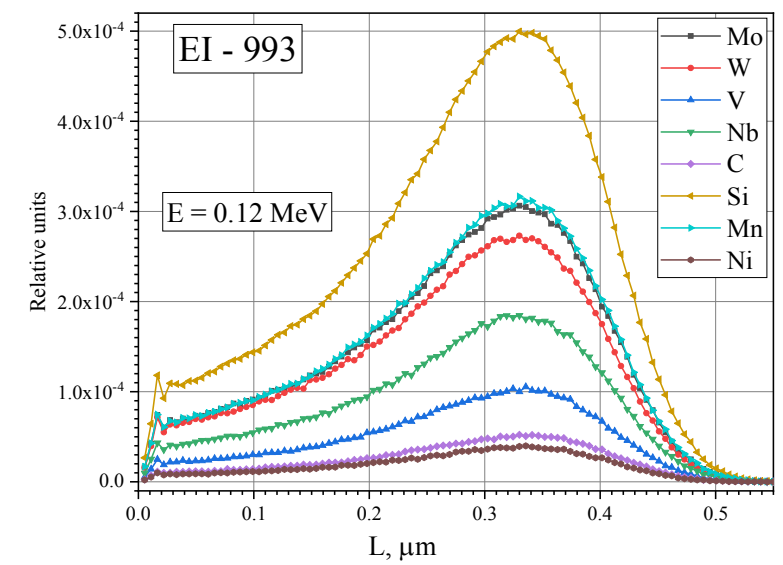

Fig. 2. Occurrence profiles of the helium and alloy the EI-993 atoms at an irradiation energy of $0.12 \mathrm{MeV}$

Table 3

Energy loss and damageability for the alloy EI-993 at energy of the helium ions irradiation of 0.12 and $4 \mathrm{MeV}$

\begin{tabular}{|l|c|c|c|}
\hline \multicolumn{4}{|c|}{ Energy loss EI-993, $\mathrm{E}_{\mathrm{He}}=0.12 \mathrm{MeV}}$. \\
Damageability - 175.3 displacements/ion
\end{tabular}

\begin{tabular}{|c|c|c|c|}
\hline \multicolumn{4}{|c|}{$\begin{array}{c}\text { Energy loss EI-993, } \mathrm{E}_{\mathrm{He}}=4 \mathrm{MeV} \text {. } \\
\text { Damageability }-303,6 \text { displacements/ion }\end{array}$} \\
\hline Parameters & $\begin{array}{c}\text { Ionization, } \\
\%\end{array}$ & $\begin{array}{l}\text { Displace- } \\
\text { ments, \% }\end{array}$ & $\begin{array}{c}\text { Phonons, } \\
\%\end{array}$ \\
\hline Ions $\mathrm{He}^{+}$ & 99.62 & 0.00 & 0.04 \\
\hline $\begin{array}{l}\text { Cascade of } \\
\text { displacement }\end{array}$ & 0.06 & 0.02 & 0.25 \\
\hline
\end{tabular}

The important role in a choice of a perspective material for the first wall and divertor of FR is played the sputtering ratio of material atoms. In the Table 4 the sputtering ratio and sputtering average energy for $\mathrm{Al}_{2} \mathrm{O}_{3}$ the helium ions irradiated with energy of 0.12 and $4 \mathrm{MeV}$ are presented.

Table 4

Sputtered atoms quantity and sputtered average energy of $\mathrm{Al}_{2} \mathrm{O}_{3}$

\begin{tabular}{|c|c|c|c|c|}
\hline \multirow{2}{*}{$\begin{array}{c}\text { Beam energy, } \\
\mathrm{E}_{\mathrm{He}}, \mathrm{MeV}\end{array}$} & \multicolumn{2}{|c|}{$\begin{array}{c}\text { Sputtered atoms } \\
\text { quantity, }\end{array}$} & \multicolumn{2}{c|}{$\begin{array}{c}\text { Sputtered } \\
\text { average energy, } \\
\text { eV/atom }\end{array}$} \\
\cline { 2 - 5 } & $\mathrm{Al}$ & $\mathrm{O}$ & $\mathrm{Al}$ & $\mathrm{O}$ \\
\hline 0.12 & 1470 & 2140 & 168.2 & 214.9 \\
\hline $\begin{array}{c}\text { Sputtered } \\
\text { ratio }\end{array}$ & \multicolumn{2}{|c|}{$3.6 \cdot 10^{-2}$} & - & - \\
\hline 4 & 40.9 & 96.9 & 4841.3 & 36.5 \\
\hline $\begin{array}{c}\text { Sputtering } \\
\text { ratio }\end{array}$ & \multicolumn{2}{|c|}{$0.14 \cdot 10^{-2}$} & - & - \\
\hline
\end{tabular}

This data also influences change of a material density along run of the helium ions range and on formation blistering and flaking processes. The given values are 
received for all alloys atoms irradiated by the helium ions on the linear accelerator.

Hence, the calculations spent in the program SRIM give us profiles of damageability and redistribution of irradiated material atoms, and also the sputtering ratio of materials atoms. These characteristics define change of density along of helium ions range. Also in the program SRIM we receive phonons ionization and formation profiles. Besides, all power characteristics calculate such as: energies, going on ionization, damageability, formations phonons and energies of atoms sputtering.

\section{EXPERIMENTAL RESEARCH TECHNIQUES}

The following experimental research techniques we develop: microscopic, measurements of electrophysical parameters of ceramic materials, measurements of frictional characteristics, ultrasonic researches.

After grinding and polishing of samples and as after a set of a certain irradiation dose microscopic researches are conducted which allow to study blistering and flaking formations and their dynamics of change from a dose irradiation and temperature, dimensional stability (swelling, "sintering"), changes of grains size, to investigate of a surface roughness and to study influence of processes of various materials dusting at an irradiation on the blistering and flaking dynamics. For this purpose microscope MMU-3 and 5 and 18 megapixel ZZCAT cameras is used.

On the Figs. 3, 4 photos of microstructures of irradiated alloy EI-993 and $\mathrm{TiO}_{2}$ are resulted respectively. On Fig. 3 blistering and flaking in alloy EI-993 is visible at an irradiation dose of $10^{18} \mathrm{~cm}^{-2}$ and temperature $450^{\circ} \mathrm{C}$. On the Fig. 4 grains and the beginning of process of superficial metallization in $\mathrm{TiO}_{2}$ at an irradiation dose of $10^{18} \mathrm{~cm}^{-2}$ are visible. Microscopic researches give the big experimental data array which can be used for forecasting of constructional materials properties and physical representations, occurring at their irradiation.
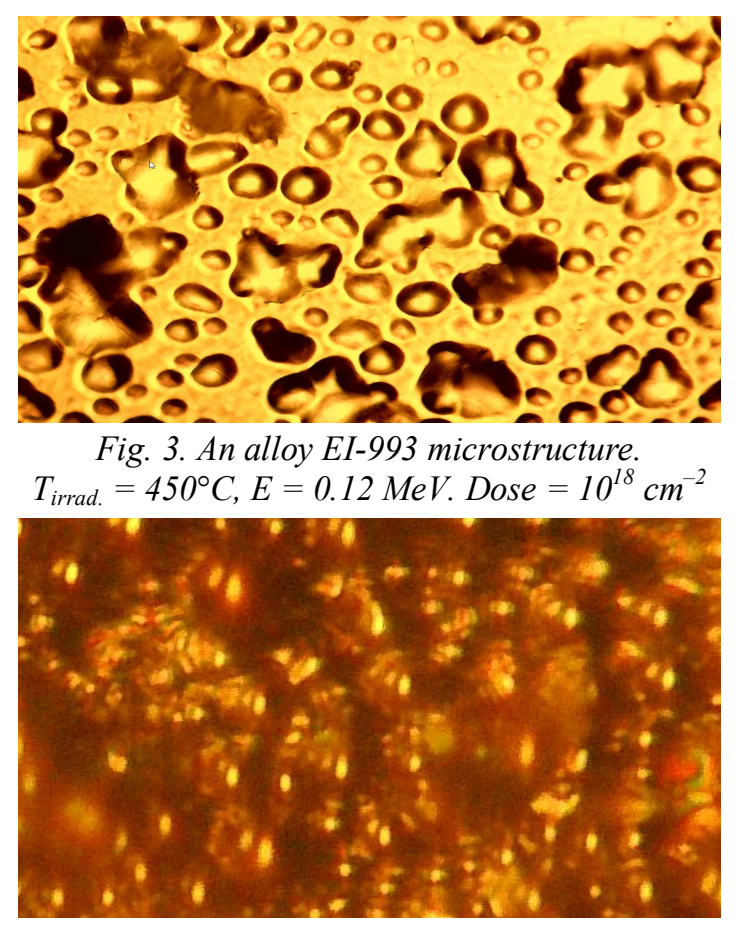

Fig. 4. $\mathrm{TiO}_{2}$ microstructure.

$$
T_{\text {irrad. }}=50^{\circ} \mathrm{C}, E=0.12 \mathrm{MeV} . \text { Dose }=10^{18} \mathrm{~cm}^{-2}
$$

Ceramic materials $\left(\mathrm{Al}_{2} \mathrm{O}_{3}, \mathrm{MgO}, \mathrm{MgAl}_{2} \mathrm{O}_{4}, \mathrm{BN}\right.$, $\mathrm{Si}_{3} \mathrm{~N}_{4}, \mathrm{TiO}_{2}$, etc.) with melting temperature from 2000 to $3000^{\circ} \mathrm{K}$ are widely applied as functional and constructional composite materials in nuclear and thermonuclear reactors [16 - 18]. Thereby researches represent a great interest of electrophysical properties of dielectrics at their irradiation and after an irradiation different spectra, including ions. The ions irradiation leads to change of some electrophysical characteristics, such as conductivity, capacity, dielectric permeability, dissipation factor and etc. Prospects of a nanotechnology application in nuclear power are connected with creation nanostructural ceramic materials and coverings of constructional elements of the atomic power station and future fusion reactors for the purpose of increase of hardness, corrosive and radiative resistance, methods development of nuclear fuel modifying and etc. On the Fig. 5, for an example, dependence of $\mathrm{TiO}_{2}$ surface electroresistance on irradiation dose is presented.

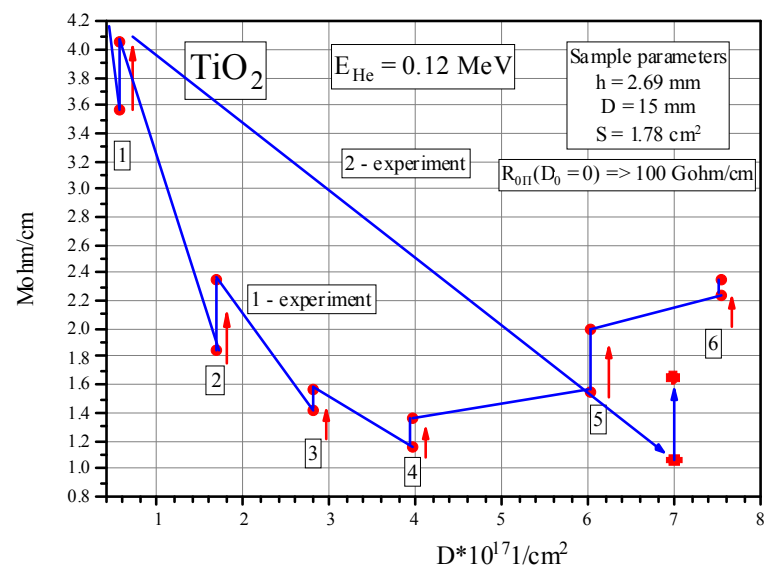

Fig. 5. Dependence of $\mathrm{TiO}_{2}$ surface electroresistance on irradiation dose

The measuring system is collected on the basis of an immitans-milliommetr gauge E7-24, the device for measurement of capacity LC100-A and developed and made megaohmmeter. From the Fig. 5 follows that at increase of an irradiation dose, electroresistance falls for account of dissipation $\mathrm{TiO}_{2}$ with the subsequent metallization of the sample surface, and after a dose $(4 \ldots 5) \cdot 10^{17} \mathrm{~cm}^{-2}$ there is a growth, it is obvious for account of partial restoration $\mathrm{TiO}_{2}$.

Characteristics of a metal - ceramics frictional interaction play an essential role in NPF the loaded knots of friction. In the couple ceramics - metal processes of carrying over of a metal and its oxides on a ceramics surface take place. As a result of it the so-called layer of carrying over is formed. For definition of these characteristics a facility has been developed and created which allows in a wide interval of temperatures to $800^{\circ} \mathrm{C}$ to define dependences of static and sliding friction factors from an irradiation dose, quantity of cycles and temperature.

On the Fig. 6 dependence of the pair $\mathrm{TiO}_{2}-$ steel sliding friction factor from quantity cycles of a frictional interaction of irradiated and not irradiated samples $\mathrm{TiO}_{2}$ at a dose of $10^{18} \mathrm{~cm}^{-2}$ and temperatures 20 and $200^{\circ} \mathrm{C}$ is resulted. From graphs follows that the irradiation leads to increase of a friction factor for account of a surface 
disturbance (the roughness is formed) and metal plating formation on a ceramics surface.

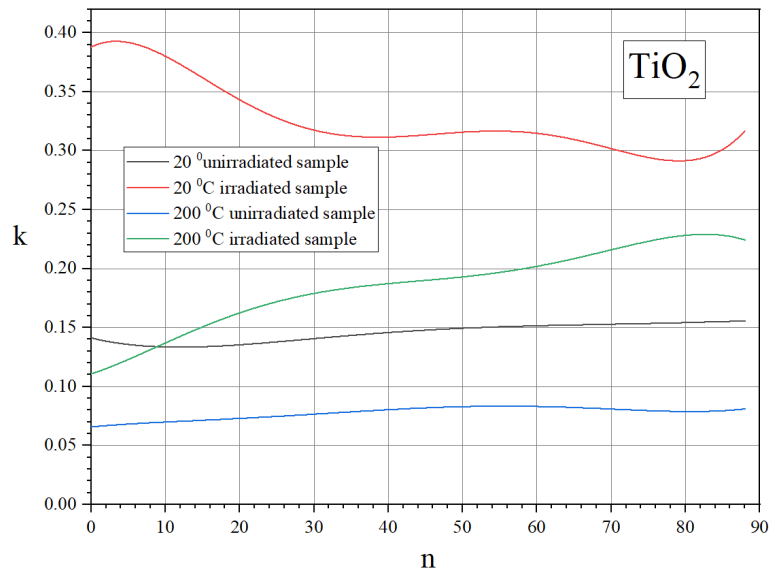

Fig. 6. Dependence of the pair $\mathrm{TiO}_{2}$ - steel sliding friction factor from quantity cycles

The ultrasonic research technique is constructed on the basis of the digital oscillograph ZET-302 and DAC/ADC ZET-210 which are connected to the computer for registration and processing of experimental data. The purpose of a developed technique is definition of materials damageability both during an irradiation, and after an irradiation. For excitation and registration of ultrasonic waves KS-P1640H12TR sensors are used.

The measurement facility consists of the receivertransmitter pair between which the investigated sample is located. Sensors work in the frequencies range $35 \ldots .50 \mathrm{kHz}$, in this range and the peak-frequency characteristic of system is measured. On the Fig. 7 calibrating curve (the top graph) and measured curve with the alloy EI-993 sample at a sinusoidal signal on an ultrasonic source are resulted. Further the measurement system will be put on the linear accelerator of helium ions with a sample under a beam.

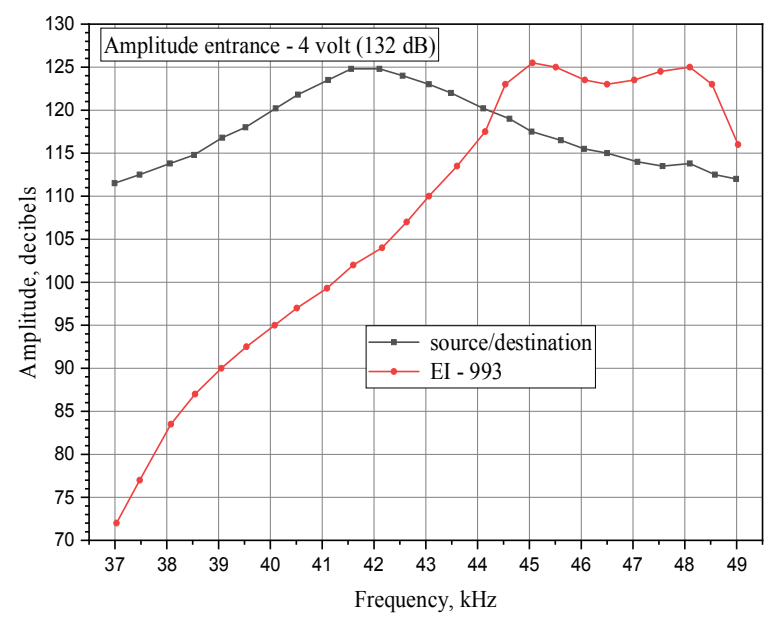

Fig. 7. The peak-frequency characteristic: calibrating curve (the top graph), the measured curve of the alloy EI-993 (the bottom graph)

\section{CONCLUSIONS}

On a basis of the helium ions linear accelerator the experimental complex for an irradiation of constructional materials samples is created. Microscopic researches, studying of electrophysical, frictional and ultrasonic characteristics of the APS and FR construc- tional materials irradiated on the linear accelerator of helium ions with energies of 0.12 and $4 \mathrm{MeV}$ are developed and implemented. Such complex approach will allow defining the basic types of perspective materials for the nuclear and thermonuclear power.

\section{REFERENCES}

1. V.N. Voyevodin. Constructional materials of nuclear power - a call of 21 centuries // Problems of Atomic Science and Technology. Series "Physics of Radiation Effects and Radiation Materials Science”. 2007, № 2, p. 10-22.

2. W. Hafele, J.P. Holden, G. Kessler, et al. Fusion and fast breeder reactors: Rep. RR-77-8 at the International Institute for Applied Systems Analysis, Luxemburg, Austria, July 1977.

3. D. Maisonnier, D. Campbell, L. Cook, et al. Power plant conceptual studies in Europe // Nuclear Fusion. 2007, v. 47, p. 1524-1532.

4. V.P. Smirnov. Thermonuclear power - the largest international innovative // Rus. Chem. J. 2008, v. LII, № 6.

5. S.V. Mirnov, E.A. Azizov, V.A. Evtikhin, et al. // Plasma Physics and Controlled Fusion. 2006, v. 48, № 6, p. 821-837.

6. M. Zucchetti, L. Di Pace, L. El-Guebaly, et al. The back end of the fusion materials cycle // Fusion Sci. Techn. 2009, v. 55, p. 109-139.

7. V.O. Bomko, O.F. Dyachenko, Ye.V. Ivakhno, et al. New prestripping section of the MILAC linear accelerator designed for accelerating a high current beam of light ions // Proceedings of EPAC 2006 Edinburgh, Scotland. 2006, p. 1627-1629.

8. S.N. Dubniuk, B.V. Zajtsev. The linear accelerator for radiation structural materials // Problems of Atomic Science and Technology. Series "Nuclear Physics Investigations”. 2014, № 3, p. 172-176.

9. V.O. Bomko, O.F. Dyachenko, O.M. Yegorov, et al. Development of investigations on the MILAC heavy ion linear accelerator // Proceedings LINAC08, Vancouver, Victoria, Canada. 2008, p. 187-189.

10. V.O. Bomko, O.F. Dyachenko, B.V. Zajtsev, et al. Inductance-capacitor system for tuning of interdigital structure of the ion linear accelerator // Problems of Atomic Science and Technology. Series "Nuclear Physics Investigations”. 2007, № 5(48), p. 180-183.

11. R.A. Anokhin, B.V. Zaitsev, K.V. Pavlii, et al. Experimental complex for investigation of construction materials on the helium ions linear accelerator // Problems of Atomic Science and Technology. Series "Nuclear Physics Investigations”. 2017, № 6, p. 167-171.

12. A.F. Dyachenko, S.N. Dubniuk, A.P. Kobets, et al. The bunch formation and transport system to the target of the helium ions linac // Problems of Atomic Science and Technology. Series "Plasma Electronics and New Methods of Acceleration". 2018, № 4(116), p. 52-55.

13. A.F. Dyachenko. Highly sensitive induction sensor of the beam-current of heavy ion linear accelerator // Journal of Kharkiv National University. Physical. Series “Nuclei, Particles, Fields”. 2010, № 887, iss. 1(45), p. 118-121. 
14. http://www.srim.org...

15. B. Widrow, J.R. Glover, J.M. McCool, et al. Adaptive noise cancelling: principles and applications // Proc. IEEE. 1963, p. 1692-1716.

16. V.M. Chernov, G.I. Khorasanov, O.A. Plaksin, et al. Electrical and optical characteristics of dielectrics for fusion use under irradiation // J. Nucl. Mater. 1998 , v. 253 , p. $175-179$.
17. V.A. Stepanov, V.M. Chernov. Radiation-induced processes and their influence on the functional properties of dielectrics for different types of irradiation // J. Nucl. Mater. 2000, v. 283/287, p. 932-936.

18. V.A. Stepanov, E.I. Isaev, L.M. Kryukova, et al. The high-dose and high-temperature monitors of reactor irradiation based on insulators // Nucl. Energy and Technology. 2015, v. 1, p. 93-98.

Article received 08.06.2021

\section{ЭКСПЕРИМЕНТАЛЬНЫЕ ИССЛЕДОВАНИЯ КОНСТРУКЦИОННЫХ МАТЕРИАЛОВ НА ЛИНЕЙНОМ УСКОРИТЕЛЕ ИОНОВ ГЕЛИЯ}

\section{В.И. Бутенко, С.Н. Дубнюк, А.Ф. Дьяченко, А.Ф. Кобец, О.В. Мануйленко, К.В. Павлий, В.А. Сошенко, С.С. Тишкин, Б.В. Зайцев}

Приведены основные параметры облучения конструкционных материалов, облучаемых на линейном ускорителе ионов гелия, и система регистрации этих параметров. Представлены экспериментальные методики и некоторые результаты исследований микроскопических, электрофизических, фрикционных и ультразвуковых характеристик конструкционных материалов атомных электрических станций и термоядерных реакторов, которые облучаются на линейном ускорителе ионов гелия с энергиями 0,12 и 4 МэВ.

\section{ЕКСПЕРИМЕНТАЛЬНІ ДОСЛІДЖЕННЯ КОНСТРУКЦІЙНИХ МАТЕРІАЛІВ НА ЛІНІЙНОМУ ПРИСКОРЮВАЧІ ІОНІВ ГЕЛІЮ}

\section{В.І. Бутенко, С.М. Дубнюк, О.Ф. Дьяченко, А.П. Кобець, О.В. Мануйленко, К.В. Павлій, В.А. Сошенко, С.С. Тіикін, Б.В. Зайцев}

Наведені основні параметри опромінення конструкційних матеріалів, що опромінюються на лінійному прискорювачі іонів гелію, та система реєстрації цих параметрів. Подано експериментальні методики й деякі результати досліджень мікроскопічних, електрофізичних, фрикційних і ультразвукових характеристик конструкційних матеріалів атомних електричних станцій і термоядерних реакторів, що опромінюються на лінійному прискорювачі іонів гелію з енергіями 0,12 і 4 МеВ. 